\title{
Antibiotic Use in Some Nigerian Communities: Knowledge and Attitudes of Consumers
}

\author{
Asa Auta ${ }^{1 *}$, Samuel B Banwat ${ }^{1}$, Shalkur David1, Dauda A Dangiwa ${ }^{1}$, Esther \\ Ogbole $^{2}$ and Amom J Tor-anyiin ${ }^{3}$ \\ ${ }^{1}$ Department of Clinical Pharmacy, University of Jos, Jos, ${ }^{2}$ Biochemistry and Chemotherapy Division, Nigerian Institute for \\ Trypanosomiasis Research, Vom, ${ }^{3}$ Institute of Human Virology Nigeria, PLASVIREC, Plateau Specialist Hospital, Jos, Nigeria \\ *For correspondence: Email: asaauta@yahoo.com; \\ Tel: +234-8030846692
}

Received: 29 May 2012

Revised accepted: 30 September 2013

\begin{abstract}
Purpose: To assess the knowledge and attitude of consumers in Jos, Nigeria towards the use of antibiotics.

Methods: A cross-sectional questionnaire survey involving 430 clients of registered community pharmacy outlets located in some communities in Jos, Nigeria was conducted in November, 2011. Data collected were analysed using SPSS version 16 and logistic regression was used to determine independent predictors of low antibiotic knowledge.

Results: About $56.5 \%$ of respondents reported using an antibiotic within a month preceding the survey, with a prevalence of $22.3 \%$ of self-medication use of antibiotics among respondents. The antibiotic knowledge assessment test revealed that $30.5 \%$ of respondents had low knowledge; while $40.9 \%$ and $28.6 \%$ of respondents had intermediate and high knowledge levels respectively. Respondents' educational level was the only demographic predictor $(p<0.01)$ of low antibiotic knowledge found, as those with primary level of education were more likely $(O R=13.224 ; C l=3.296-53.052)$ to have low antibiotic knowledge than those with tertiary education. Respondents showed negative attitude $(<50 \%$ positive response rate) in about $60 \%$ of the attitude statements they responded to. The most common negative attitudes demonstrated by respondents were their expectation to be prescribed an antibiotic for cold $(66.3 \%)$ and taking an antibiotic when they have cold to get better quickly (60.9\%). However, respondents demonstrated positive attitudes in looking at the expiry dates of antibiotics before using them (93.3 \%), and taking antibiotics according to the instructions on the label (84.2\%).

Conclusion: The study showed that inadequate antibiotic knowledge and negative attitudes towards antibiotics use exists among consumers.
\end{abstract}

Keywords: Antibiotic use, knowledge, attitude, Nigerian consumers.

Tropical Journal of Pharmaceutical Research is indexed by Science Citation Index (SciSearch), Scopus, International Pharmaceutical Abstract, Chemical Abstracts, Embase, Index Copernicus, EBSCO, African Index Medicus, JournalSeek, Journal Citation Reports/Science Edition, Directory of Open Access Journals (DOAJ), African Journal Online, Bioline International, Open-J-Gate and Pharmacy Abstracts

\section{INTRODUCTION}

Antibiotics are cost effective interventions for the treatment and prevention of infectious diseases. Their use has however, been accompanied by increased prevalence of resistance which presents a threat to public health. Resistance to antibiotics is a common problem worldwide and it has been associated with inappropriate use including failure to complete treatment, skipping of doses, re-use of leftover medicines, and overuse of antibiotics [1].

Resistance to antibiotics have been reported in Nigeria. Ghebremedhin et al [2], reported the emergence of a community-associated methicillin -resistant Staphylococcus aureus in southwest 
Nigeria while Lamikanra et al. [3], reported the rapid evolution of flouroquinolone-resistant Escherichia coli in a Nigerian community. Okesola and Oni [4], also reported high antibiotics resistance rates among common Gram-positive and Gram-negative isolates from various clinical specimens brought in a tertiary hospital in Nigeria.

Appropriate use of antibiotics in the society requires correct knowledge and attitude. Public knowledge and attitude towards antibiotics usage have been investigated. Sun et al [5], studied the knowledge and attitude of South Koreans towards antibiotic use and concluded that a general misunderstandings and lack of knowledge exists among the studied population. Oh et al. [6], conducted a survey on antibiotics knowledge and attitude among Malaysian adults and concluded that educational interventions are needed to promote appropriate use of antibiotics among the public.

There is limited data concerning the knowledge and attitude of Nigerians towards the use of antibiotics. Hence, this study was carried out to assess the knowledge and attitude of Nigerian consumers towards the use of antibiotics.

\section{METHODS}

\section{Study setting}

The study was conducted in 4 communities (Angwan Rukuba, Tina, Naraguta and Angwan Rogo) around the University of Jos, located in Jos, north-central, Nigeria. There are about 10 registered community pharmacy outlets in these communities. This study utilised 6 of the registered community pharmacy outlets as sites for the recruitment of study participants.

\section{Study design}

A descriptive, cross sectional survey was conducted in November 2011 on 430 community pharmacy clients. The study population was obtained through a convenience sampling design. Six registered community pharmacies were selected and used as study sites for this study based on their accessibility and client's volume. Clients from these pharmacy outlets were recruited for the study if they were at least 18years old; understood English language and were aware of the term antibiotics.

The questionnaire used for this study was adapted from previous studies and adjusted to fit into the local context [6-8]. The questionnaire was pretested on 40 members of the general public and then adjusted as appropriate. The pretested questionnaire was administered to participating pharmacy clients. The questionnaire administered was divided into four domains. The first domain consisted of the demographic details of the respondent; the second domain consisted of questions related to antibiotic use within a month preceding the survey; the third domain consisted of statements related to the attitude of respondent towards antibiotics use and was assessed using a five-point Likert scale ranging from "Strongly Agree" to "Strongly Disagree". The fourth domain was a knowledge assessment test consisting of 14 dichotomous knowledge items to test respondents' knowledge on key areas of antibiotics indication, identification, dangers and administration.

\section{Ethical consideration}

Approval to carry out the study in each community pharmacy was obtained from the managers of the community pharmacies. Verbal informed consent was sought from each participant before administering the questionnaire and participants were told that participation in the study was voluntary and information obtained would be anonymous and confidential.

\section{Data analysis}

Data were entered into the Statistical Package for Social Sciences (SPSS) version 16.0 (SPSS Inc, Chicago IL) to generate descriptive statistics. Relationships between variables were tested using chi-square test. The knowledge assessment test was evaluated by scoring each correct response as one (1) while an incorrect response was scored zero $(\mathrm{O})$. Thus, there were 0 to 14 possible scores. The percentage distribution of the antibiotics knowledge scores was determined and then used to classify respondents' knowledge levels based on percentiles. Those whose scores were $\leq 25^{\text {th }}$ percentiles were considered to have low antibiotics knowledge while those whose scores were $\geq 75^{\text {th }}$ percentiles were considered to have high antibiotics knowledge. Respondents whose knowledge scores were greater than $25^{\text {th }}$ percentile but less than $75^{\text {th }}$ percentile were regarded to have an intermediate knowledge level. Logistic regression analysis was used to determine the independent predictors of low antibiotics knowledge in the studied population.

\section{RESULTS}

A total of 478 questionnaires were distributed to community pharmacy clients but only 430 of 
them were completely filled and returned, thus representing a response rate of $89.96 \%$. Most of the respondents were young people (between 18 -30 years old) and students (table 1).

Table 1: Demographic characteristics of respondents

\begin{tabular}{lc}
\hline Variable & $\mathbf{n ~ ( \% )}$ \\
\hline Gender & \\
Male & $211(49.1)$ \\
Female & $219(50.9)$ \\
Age (years) & \\
$18-30$ & $303(70.5)$ \\
$31-40$ & $81(18.8)$ \\
$41-50$ & $31(7.2)$ \\
$51-60$ & $15(3.5)$ \\
Educational level & \\
Primary & $13(3.0)$ \\
Secondary & $90(20.9)$ \\
Tertiary & $327(76.0)$ \\
Occupation & \\
Students & $249(57.9)$ \\
Civil servants & $72(16.7)$ \\
Business men/women & $49(11.4)$ \\
Private sector employee & $28(6.5)$ \\
Unemployed & $15(3.5)$ \\
Others & $17(4.0)$ \\
\hline$N=430$ &
\end{tabular}

About $56.5 \%(n=242)$ of respondents reported using an antibiotic within a month preceding the survey. Only $60.3 \%(n=146)$ of those that reported using an antibiotic within a month preceding the survey got it from a doctor's prescription while $39.7 \%(n=96)$ reported getting them on self-medication, which represents a prevalence of $22.3 \%$ of selfmedication use of antibiotics in the studied population.

The antibiotic knowledge assessment test revealed that $30.5 \%$ of respondents had low knowledge level and scored between $0-6$ points while $40.9 \%$ (scored between 7-10 points) and $28.6 \%$ (scored between 11 - 14 points) of respondents had intermediate and high knowledge levels respectively. No respondent scored zero point but a few patients $(0.9 \%)$ had a total score of 14 points which was the maximum score. The modal knowledge assessment score was 11 (Figure 1).

Respondents in this study had high knowledge in the use of antibiotics in the treatment bacterial infections (91.2 \% correct response), identification of ampicillin as an antibiotic $(85.3 \%$ correct response) and in recognising that overuse of an antibiotics can cause resistance (75.8 \%). However, about $70.7 \%$ of respondents wrongly reported that antibiotics are used in the treatment of viral infections (Table 2).

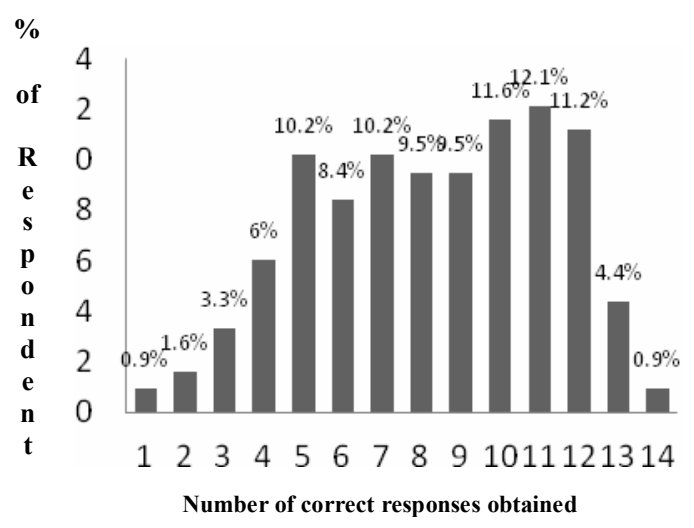

Figure 1: Distribution of correct knowledge responses

Table 2: Antibiotic knowledge assessment items and percentage of respondents with correct response

\begin{tabular}{|c|c|c|}
\hline Knowledge assessment item & $\begin{array}{l}\text { Response } \\
\text { option* }\end{array}$ & $\begin{array}{c}\% \\
\text { Correct } \\
\text { response } \\
\end{array}$ \\
\hline \multicolumn{3}{|l|}{ Antibiotics indication } \\
\hline $\begin{array}{l}\text { Antibiotics are medicines that } \\
\text { can kill bacteria }\end{array}$ & True & 91.2 \\
\hline $\begin{array}{l}\text { Antibiotics can be used to treat } \\
\text { viral infections }\end{array}$ & False & 29.3 \\
\hline $\begin{array}{l}\text { Antibiotics can cure all } \\
\text { infections }\end{array}$ & False & 60.7 \\
\hline $\begin{array}{l}\text { Antibiotics are used to relieve } \\
\text { body pain }\end{array}$ & False & 57.4 \\
\hline $\begin{array}{l}\text { Antibiotics are used to stop } \\
\text { fever }\end{array}$ & False & 51.2 \\
\hline \multicolumn{3}{|l|}{ Antibiotics identification } \\
\hline Paracetamol is an antibiotic & False & 71.6 \\
\hline Ampicillin is an antibiotic & True & 85.3 \\
\hline Piriton is an antibiotic & False & 36.5 \\
\hline $\begin{array}{l}\text { Aspirin is a new generation } \\
\text { antibiotic } \\
\text { Dangers associated with } \\
\text { antibiotics }\end{array}$ & False & 47.4 \\
\hline $\begin{array}{l}\text { Overuse of antibiotics can } \\
\text { cause antibiotic resistance }\end{array}$ & True & 75.8 \\
\hline $\begin{array}{l}\text { Antibiotics can cause allergic } \\
\text { reaction }\end{array}$ & True & 59.3 \\
\hline $\begin{array}{l}\text { All antibiotics do not have side } \\
\text { effects } \\
\text { Antibiotics administration }\end{array}$ & False & 68.1 \\
\hline $\begin{array}{l}\text { Antibiotics may be effective } \\
\text { even if you did not complete } \\
\text { treatment }\end{array}$ & False & 50.7 \\
\hline $\begin{array}{l}\text { You can stop taking antibiotics } \\
\text { if you are well }\end{array}$ & False & 42.5 \\
\hline
\end{tabular}

Low knowledge level was prevalent among respondents with primary education $(76.9 \%)$, and when logistic regression was applied to the data obtained from this study, the educational level of respondents was found to be the only demographic predictor $(p<0.01)$ of low antibiotic knowledge in the study population. The results revealed that respondents with 
primary level of education were 13.2 times more likely to have low antibiotic knowledge than those

with tertiary education (Table 3).

Table 3: Multivariate adjusted odd-ratios of low antibiotic knowledge

\begin{tabular}{|c|c|c|c|}
\hline 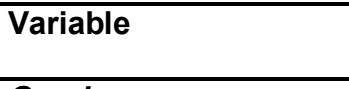 & $\begin{array}{c}\text { Prevalence of low antibiotic } \\
\text { knowledge (\%) }\end{array}$ & OR (95\% Cl) & $P$-value \\
\hline \multicolumn{4}{|l|}{ Gender } \\
\hline Male & 28.4 & Referent & \\
\hline Female & 32.4 & $1.215(0.780-1.880)$ & 0.382 \\
\hline \multicolumn{4}{|l|}{ Age (years) } \\
\hline $18-30$ & 33.3 & $4.903(0.899-26.751)$ & 0.066 \\
\hline $31-40$ & 27.2 & $3.555(0.644-19.618)$ & 0.146 \\
\hline $41-50$ & 19.4 & $2.001(0.307-13.038)$ & 0.468 \\
\hline $51-60$ & 13.3 & Referent & \\
\hline \multicolumn{4}{|l|}{ Educational level } \\
\hline Primary & 76.9 & $13.224(3.296-53.052)$ & 0.000 \\
\hline Secondary & 40.0 & $1.765(1.063-2.930)$ & 0.028 \\
\hline Tertiary & 26.0 & Referent & \\
\hline \multicolumn{4}{|l|}{ Occupation } \\
\hline Students & 32.0 & Referent & \\
\hline Civil servants & 23.9 & $0.862(0.260-2.858)$ & 0.809 \\
\hline Business men/women & 32.7 & $0.811(0.224-2.938)$ & 0.750 \\
\hline Private sector employee & 28.6 & $1.186(0.323-4.355)$ & 0.797 \\
\hline Unemployed & 26.7 & $0.789(0.188-3.316)$ & 0.789 \\
\hline Others & 35.3 & $0.754(0.145-3.928)$ & 0.737 \\
\hline \multicolumn{4}{|l|}{ Recently took antibiotic } \\
\hline Yes & 27.7 & Referent & \\
\hline No & 33.9 & $1.447(0.930-2.251)$ & 0.101 \\
\hline \multicolumn{4}{|c|}{ Got antibiotic on prescription } \\
\hline Yes & 30.1 & & \\
\hline & 27.1 & $1.237(0.670-2.284)$ & 0.496 \\
\hline Overall & 30.5 & Referent & \\
\hline
\end{tabular}

Table 4: Attitude of respondents towards antibiotic use

\begin{tabular}{|c|c|c|c|c|}
\hline Attitude statement ${ }^{*}$ & $\begin{array}{l}\text { Agree } \\
\text { n (\%) }\end{array}$ & $\begin{array}{c}\text { Disagree } \\
\mathrm{n}(\%)\end{array}$ & $\begin{array}{l}\text { Unsure } \\
\text { n (\%) }\end{array}$ & $\begin{array}{c}\text { Demographic } \\
\text { factor associated } \\
\text { with statement } \\
(p \text {-value }) \\
\end{array}$ \\
\hline $\begin{array}{l}\text { When I get cold, I will take antibiotics to help me } \\
\text { get better quickly }\end{array}$ & $262(60.9)$ & $141(32.8)$ & $27(6.3)$ & None \\
\hline $\begin{array}{l}\text { I expect antibiotics to be prescribed by my } \\
\text { doctor if I suffer from common cold }\end{array}$ & $285(66.3)$ & $126(29.3)$ & $19(4.4)$ & $\begin{array}{c}\text { Age }(0.012) \\
\text { Occupation }(0.016)\end{array}$ \\
\hline $\begin{array}{l}\text { I normally stop taking antibiotics when I start } \\
\text { feeling better. }\end{array}$ & $211(49.1)$ & $190(44.2)$ & $29(6.7)$ & None \\
\hline $\begin{array}{l}\text { If my family member is sick, I usually will give } \\
\text { him my antibiotics if his illness is similar to mine }\end{array}$ & $206(47.9)$ & $201(46.7)$ & $23(5.4)$ & None \\
\hline $\begin{array}{l}\text { I normally keep antibiotics at home in case of } \\
\text { emergency }\end{array}$ & $241(56.1)$ & $173(40.2)$ & $16(3.7)$ & None \\
\hline I will use leftover antibiotics if I am sick & $148(34.4)$ & $269(62.6)$ & $13(3.0)$ & None \\
\hline $\begin{array}{l}\text { I don't need to see a doctor for a prescription if I } \\
\text { know the antibiotic to use for my illness }\end{array}$ & $226(52.6)$ & $169(39.3)$ & $35(8.1)$ & Age $(0.003$ \\
\hline $\begin{array}{l}\text { Will take antibiotics according to the instruction } \\
\text { on the label }\end{array}$ & $362(84.2)$ & $54(12.6)$ & $14(3.3)$ & None \\
\hline $\begin{array}{l}\text { Normally will look at the expiry date of an } \\
\text { antibiotic before it. }\end{array}$ & 401(93.3) & $18(4.2)$ & $11(2.6)$ & Education (0.006) \\
\hline
\end{tabular}

${ }^{*}$ Respondents with positive attitude indicated in bold

Most respondents in this study demonstrated negative attitude towards antibiotic use as less than $50 \%$ positive response rate was obtained in most of the attitude statements (Table 4). The 
most common negative attitudes demonstrated by respondents were their expectation to be prescribed an antibiotic when they suffer from common cold and taking an antibiotic when they have cold to help get better quickly. However, respondents demonstrated positive attitudes in looking at the expiry dates of antibiotics before using it (93.3 \%); taking antibiotics according to the instructions on the label (84.2\%); and not using leftover antibiotics when they are sick (62.6 $\%)$.

\section{DISCUSSION}

Most respondents who participated in this study were young people and students. This is because the communities where the research was carried out are located around the University and these communities have high proportions of university students. In addition, it is a tradition in Africa for elderly people to send young people on errand; hence this may have contributed to the high proportion of young people as clients of community pharmacies.

This research revealed high use of antibiotics in the study population with one in two persons reporting using an antibiotic within a month preceding the survey. The high use of antibiotics in a population can result in an increase in the ecological pressure for resistance [9]. High antibiotics self-medication rate $(22.3 \%)$ was also reported among respondents. Antibiotics are "Prescription Only Medicines" in Nigeria, which means that by policy or regulation, they are only supposed to be issued to a patient with a prescription. However, individuals self-medicate with them because they can purchase these medicines over-the-counter in Nigeria [10]. This shows that the sales of pharmaceutical products in the country are under-regulated and this has led to a high incidence of self-medication with prescription medicines; adverse drug events; treatment failures; and antimicrobial resistance in the country [11].

In the knowledge assessment, about one in three respondents had low antibiotic knowledge and the educational level of respondents was found to be a predictor of low knowledge (table 3 ). This finding also confirms the findings by McNulty et al [12], who reported that lower educational level was the greatest determinant of low antibiotic knowledge. Respondents had very low knowledge in the use of antibiotics in the treatment of viral infections and in differentiating other commonly used over-the-counter medicines from antibiotics (Table 3). The proportion of respondents in this study that incorrectly thought that antibiotics are used in the treatment of viral infections (70.3 \%) is comparable to that obtained in a survey in New Jersey $(70 \%)$ and Malaysia $(67.2 \%)[6,13]$.

Most respondents $(60.9 \%)$ in this study would take antibiotics for a cold. The proportion of people reporting using antibiotics for cold is higher than that found in most studies including Malaysia (38 \%) [6], Hong Kong (17\%) [7] and America (27 \%) [8]. About 90\% of all upper respiratory tract infections are caused by viruses, which do not respond to antibiotic treatment and this can create a selective pressure for the development of resistant strains of pathogens [13].

A high proportion of respondents expect an antibiotic to be prescribed to them when they have cold (66.3 \%). Patients' expectations have been shown to contribute to inappropriate prescribing of antibiotics. Mangione-Smith et al [14], demonstrated that physicians' perceptions of parental expectations for antibiotics were the only significant predictor of prescribing antibiotics for conditions of presumed viral aetiology. It has also been shown that physicians would like to meet patients' expectation even though they feel antibiotics are unnecessary [15]. A study revealed that public education targeted at changing patient behaviour can contribute significantly to reducing the rate of inappropriate use of antibiotics [1]. Hence, there is need for patients to be educated on the difference between viral and bacterial infections; and advising them not to take an antibiotic for viral illness.

Antibiotic medication sharing behaviour was found to be very common among respondents as about $48 \%$ of them would give their antibiotics to their family members if they feel they have similar illness with theirs (table 4). Although this attitude was not associated with age in this study, medication sharing behaviour has been shown to be common among young people [16]. Respondents' attitude towards sharing of antibiotics in this study was unsurprising because our previous findings have demonstrated that antibiotics were among the common medications shared by students of the University community [16].

In this study, respondents demonstrated a very high positive attitude $(93.3 \%)$ towards the checking of the expiry dates of antibiotics before use and this is comparable to that obtained in a study in Malaysia where $92.2 \%$ of respondents reported that they will look at the expiry date of antibiotics before taking it [6]. This positive attitude demonstrated by respondents may be as 
a result of the increased awareness created by the National Agency for Food, Drug Administration and Control (NAFDAC) on the need to check the expiry dates of medicine at the point of sale or administration due to the presence of fake and expired medicines in the Nigerian market [17].

\section{Study limitations}

Some limitations are associated with this study and are likely to affect the generalisation of our findings. This study excluded the non-literate members of the communities and consumers who obtain their medicines from sources other than the community pharmacy. Hence, this study might not have captured the attitude of these groups of individuals. The convenience sampling design used for this study may be associated with a selection bias as some categories of clients might have been over-selected, or underselected or missed.

\section{CONCLUSION}

This study shows that inadequate antibiotic knowledge exists among respondents and most respondents displayed negative attitudes towards antibiotics use. Hence, there is need for public education to promote appropriate use of antibiotics.

\section{ACKNOWLEDGEMENT}

Authors wish to appreciate all the 4th year undergraduate pharmacy students (2010/2011 session) of the Faculty of Pharmaceutical Sciences, University of Jos, Jos, Nigeria that assisted in data collection.

\section{REFERENCES}

1. Hemo B, Shamir-Shtein NH, Silverman BG, Tsamir J, Haymann AD, Tsehori S, Friedman NL. Can a nationwide media campaign affect antibiotic use? Am J Manag Care 2009; 15(8): 529-538.

2. Ghebremedhin B, Olugbosi Mo, Raji AM, Layer $F$, Bakare RA, Konig B, Konig W. Emergence of a community-associated methicillin-resistant Staphylococcus aureus strain with a unique resistance profile in southwest Nigeria. J Clin Microbiol 2009; 47(9): 2975-2980.

3. Lamikanra A, Crowe JL, Lijek RS, Odetoyin DW, Wain $J$, Aboderin AO, Okeke IN. Rapid evolution of of fluoroquinolone-resistant Escherichai coli in Nigeria is temporarily associated with fluoroquinolone use. BMC Infect Dis 2011; 11: 312.

4. Okesola AO, Oni AA. Antimicrobial resistance among common bacterial pathogens in south western Nigeria. American-Eurasian J Agric Environ Sci 2009; 5(3): 327-330.

5. Sun SK, Seongmi M, Jung KE. Public knowledge and attitudes regarding antibiotic use in South Korea. $J$ Korean Acad Nurs 2011; 41(6): 742-749.

6. Oh LA, Hassali MA, Al-Haddad MS, Sulaiman SAS, Shafie AA, Awaisu A. Public knowledge and attitudes towards antibiotics usage: a crosssectional study among the general public in the state of Penang, Malaysia. J Infect Dev Ctries 2011; 5(5): 338-347.

7. You JHS, Yau B, Choi KC, Chau CTS, Huang OR, Lee SS. Public Knowledge, attitudes and behaviour on antibiotic use: a telephone survey in Hong Kong. Infection 2008; 36: 153-157.

8. Eng JV, Marcus R, Hadler JL, Imhoff B, Vugia DJ, Cieslak PR, Zell E, Deneen V, McCombs KG, Zansky SM, et al. Consumer attitude and use of antibiotics. Emerg Infect Dis 2009; 9(9): 11281135.

9. Reeves DS, Finch RG, Bax RP, Davey PG, Po ALW, Lingam $G$, et al. Self-medication of antibacterials without prescription (also called 'over-the-counter' use) A report of a Working Party of the British Society for Antimicrobial Chemotherapy. J Antimicrob Chemother. 1999; 44 (2): 163-177.

10. Auta A, Banwat SB, Dayom DW, Shalkur D, Avu MO. Occurrence and treatment of common health problems in a Nigerian community. J Young Pharmacists. 2012; 4: 49-53.

11. Okwonkwo AD, Okwonkwo UP. Patent medicine vendors, community pharmacist and STI management in Abuja, Nigeria. Afr Health Sci 2010;10:253-65.

12. McNulty CAM, Boyle $P$, Nichols T, Clappison P, Davey $P$. The public's attitude to and compliance with antibiotics. J. Antimicrob Chemother 2007; 60(Supppl 1): i63-i68.

13. Filipetto FA, Modi DS, Weiss LB, Ciervo CO. Patients knowledge and perception of upper respiratory tract infections, antibiotic indication and resistance. Patient Prefer Adherence 2008; 2: 35-39.

14. Mangione-Smith R, McGlynn EA, Elliott MN, Krogstad P, Brook $R H$. The relationship between perceived parental expectations and paediatrician antimicrobial prescribing behaviour. Pediatrics 1999; 103(4): 711-718.

15. Butler CC, Rollnick S, Pill R, Maggs-Rapport F, Stott N. Understanding the culture of prescribing: qualitative study of general practitioners' and patients' perceptions of antibiotics for sore throats. BMJ 317: 637-642.

16. Auta A, Banwat SB, Francis RA. Prevalence of prescription medication sharing behaviour among students. IJPLS 2011; 2(4): 651-654.

17. Akunyili D. Fake and Counterfeit drugs in the health sector: The role of medical doctors. Ann Ibd Pg Med 2004; 2(2): 19-23 